\title{
Affected Model of Indoor Radon Concentrations Based on Lifestyle, Greenery Ratio, and Radon Levels in Groundwater
}

\author{
Hyun Young Lee', Ji Hyun Park², Cheol-Min Lee ${ }^{3}$, Dae Ryong Kang ${ }^{4}$ \\ ${ }^{1}$ Department of Statistics, Clinical Trial Center, Ajou University Medical Center, Suwon; ${ }^{2}$ Department of Mathematics, Ajou University, Suwon; \\ ${ }^{3}$ Department of Chemical and Biological Engineering, Seokyeong University, Seoul; ${ }^{4}$ Center of Biomedical Data Science, Wonju College of Medicine Yonsei \\ University, Wonju, Korea
}

Objectives: Radon and its progeny pose environmental risks as a carcinogen, especially to the lungs. Investigating factors affecting indoor radon concentrations and models thereof are needed to prevent exposure to radon and to reduce indoor radon concentrations. The purpose of this study was to identify factors affecting indoor radon concentration and to construct a comprehensive model thereof. Methods: Questionnaires were administered to obtain data on residential environments, including building materials and life style. Decision tree and structural equation modeling were applied to predict residences at risk for higher radon concentrations and to develop the comprehensive model. Results: Greenery ratio, impermeable layer ratio, residence at ground level, daily ventilation, long-term heating, crack around the measuring device, and bedroom were significantly shown to be predictive factors of higher indoor radon concentrations. Daily ventilation reduced the probability of homes having indoor radon concentrations $\geq 200 \mathrm{~Bq} / \mathrm{m}^{3}$ by $11.6 \%$. Meanwhile, a greenery ratio $\geq 65 \%$ without daily ventilation increased this probability by $15.3 \%$ compared to daily ventilation. The constructed model indicated greenery ratio and ventilation rate directly affecting indoor radon concentrations. Conclusions: Our model highlights the combined influences of geographical properties, groundwater, and lifestyle factors of an individual resident on indoor radon concentrations in Korea.

Key words: Indoor radon, Radon survey, Ventilation, Geographical properties, Lifestyle, Groundwater

\section{INTRODUCTION}

Many people spend most of their day indoors, where low concentrations of radon (Rn-222) pose a significant environmental risk. Radon is a gas that decays from uranium (U-238). Its progeny can attach to aerosol and dust, and tends to get into the lungs [1]. In a previous study, $40 \%$ of all lung cancer deaths among miners were found to be related with radon progeny exposure. Indeed, $10 \%$ of all lung cancers may be caused by exposure to radon indoors: interestingly, these percentages were higher in never smokers than in smokers [2]. Another study proposed that radon poses a higher risk upon prolonged exposure at low doses than shorter exposure at higher doses [3]. Accordingly, the World Health Organization has pronounced radon as the second leading cause of lung

Corresponding author: Dae Ryong Kang

20 Ilsan-ro, Wonju 26426, Korea

Tel: +82-33-742-0929, E-mail: dr.kang@yonsei.ac.kr

Received: October 13, 2017 Revised: November 16, 2017 Accepted: November 20, 2017

No potential conflict of interest relevant to this article was reported.

*The study was supported by the Korean Ministry of Environment as part of the 'Environmental Health Action Program' [grant number 2015001350002] and this work was supported by the faculty research fund of Ajou University School of Medicine. cancers after smoking and has indicated the health risk of radon to be related with indoor radon concentrations [4]. Indeed, in a previous study on women with lung cancer, the risk of radon exposure was significantly elevated with increasing indoor radon concentrations $(<37,37-73,74-$ $147, \geq 148 \mathrm{~Bq} / \mathrm{m}^{3}$ ). To minimize the health risk associated with indoor radon exposure, reference levels of indoor radon concentrations have been proposed: $148 \mathrm{~Bq} / \mathrm{m}^{3}$ (Becquerel per cubic meter) by the United States Environmental Protection Agency, $100 \mathrm{~Bq} / \mathrm{m}^{3}$ by the World Health Organization, and $200 \mathrm{~Bq} / \mathrm{m}^{3}$ by the International Commission on Radiological Protection [4-6].

In Korea, the Ministry of Environment has continued to measure radon levels via the "Indoor Air Quality Radon Management Plan" during 3 months of the winter season. From 2011 to 2014, the average in-

How to cite this article:

Lee HY, Park JH, Lee CM, Kang DR. Affected model of indoor radon concentrations based on lifestyle, greenery ratio, and radon levels in groundwater. J Health Info Stat 2017;42(4):309-316. Doi: https://doi. org/10.21032/jhis.2017.42.4.309

(c) It is identical to the Creative Commons Attribution Non-Commercial License (http://creativecommons.org/licenses/by-nc/4.0) whichpermit sunrestricted non-commercial use, distribution, and reproduction in any medium, provided the original work is properly cited.

(c) 2017 Journal of Health Informatics and Statistics 
door radon concentration was 102.0-126.3 Bq/ $\mathrm{m}^{3}$ (https://iaqinfo.nier. go.kr). Radon concentrations, however, have been found to differ widely across Korean province, ranging from 52.6 to $213.3 \mathrm{~Bq} / \mathrm{m}^{3}$. Meanwhile, studies have demonstrated that indoor radon concentration are associated with building construction and the permeability of ground materials [7], building materials have also been found to have a small effect on indoor radon concentrations [8]. In addition, characteristics of rocks distributed around residence have effect on indoor radon concentrations [9]. The components of the rock are dissolved in groundwater. Accordingly, this means that radon levels in groundwater can be a predictor of the degree of radon content in the surrounding ground.

The present study had three major objectives: (1) to identify factors affecting indoor radon concentrations, including lifestyle, geographical properties, and building materials, (2) to suggest action guidelines for reducing indoor radon concentrations through decision tree analysis, and (3) to construct a comprehensive model reflective of indoor radon concentrations in Korea.

\section{METHODS}

\section{Indoor radon dosimetry}

In this study, indoor radon concentration was collected and analyzed for 3 months during Korean winter season. Between October 28, 2015 and March 30, 2016, 518 radon measurements at 263 residences were obtained. The subjects who voluntarily participated in 30 cities and counties were surveyed. Alpha-track detectors (Raduet Model RSV-8, Radosys Ltd., Budapest, Hungary) were used as a passive radon measuring device. The average concentration of radon in the indoor air was calculated from two points within the household. The measurement points were selected from the living room and a bedroom, spaces where residents of a household primarily spend most of their time. The measuring devices were positioned away from household electrical appliances, windows, and sealed drawers. The measurement period was 3 months.

As measurements started in different months for targeted households, we analyzed mean radon concentrations with standard deviations according to installation month: $119.5 \pm 21.0 \mathrm{~Bq} / \mathrm{m}^{3}$ in October $(\mathrm{n}=2)$, 123.7 $\pm 88.0 \mathrm{~Bq} / \mathrm{m}^{3}$ in December $(\mathrm{n}=292)$, and $111.8 \pm 82.2 \mathrm{~Bq} / \mathrm{m}^{3}$ in January $(n=224)$. There were no statistical differences in the mean radon concentrations for each month of installation ( $p=0.296$ by ANOVA, data not shown).

\section{Residential environment}

Questionnaires on the residential environment of 263 residences were administered. The questionnaires assessed residential location, type of house, building materials, ventilation, the foundation of the residence, groundwater usage, and information on the position of the radon measuring equipment. According to the Environmental Geographic Information Service (https://eais.me.go.kr) maintained by the Ministry of Environment in Korea, residential locations were converted to greenery ratios and impermeable layer ratios [10,11]. Greenery and impermeable layer ratios reflect the area of green and impermeable layer space in comparison to the administrative area by state/province. Green area corresponds to forest and grassland area; agricultural space, such as rice fields, is not included in green area. Impermeable layer refers to the area covered with pavement or a building, where rainwater does not infiltrate the ground. Based on natural radionuclides in groundwater by the Korea Institute of Geoscience and Mineral Resources and Soil and Groundwater Division, National Institute of Environmental Research, 222-radon groundwater concentrations were assigned to each residence [12-14]. The study protocol with residence questionnaires was reviewed and approved by the Korean Ministry of Environment (Protocol no. 2015001350004).

\section{Statistical analysis}

Indoor radon concentrations are presented as means with standard deviations and geometric means. To consider repeated measures within the same residence, a generalized estimating equation with a linear model was applied according to individual residential environments. To identify factors affecting higher indoor radon concentrations, we divided residences into five groups according to radon concentrations based on indoor radon reference levels as international standards $\left(<74 \mathrm{~Bq} / \mathrm{m}^{3}, 74\right.$ $100 \mathrm{~Bq} / \mathrm{m}^{3}, 100-148 \mathrm{~Bq} / \mathrm{m}^{3}, 148-200 \mathrm{~Bq} / \mathrm{m}^{3}$, and $\left.\geq 200 \mathrm{~Bq} / \mathrm{m}^{3}\right)$ and $\mathrm{ap}-$ plied a generalized estimating equation based on a multinomial probability distribution with a cumulative probit link function. Spearman's rho was used to analyze correlations among greenery ratio, impermeable layer ratio, and indoor radon concentrations. Decision tree analysis was conducted to highlight factors and to suggest optimal cut point of each parameter affecting high indoor radon concentrations by exhaustive chisquared automatic interaction detection (CHAID), as a growing method. Also, random validation was performed with $80 \%$ training and $20 \%$ testing sets. To construct an affected model of indoor radon concentrations, structural equation modeling (SEM) as confirmatory multivariate 
analysis was applied with AMOS 21.0 (SPSS Inc., Chicago, IL, USA). Although the $\chi^{2}$ to degrees of freedom ratio has no exact interpretation, it has been suggested that values of $\chi^{2} / d f<2$ are indicative of an acceptable fit for a hypothetical model [15]. SPSS 23.0 (SPSS Inc., Chicago, IL, USA) was used for statistical analysis except SEM.

\section{RESULTS}

\section{Residential environments}

Table 1 presents radon concentrations according to residential structure, building materials, lifestyles of the resident, and the positioning of measuring equipment. European-style, detached houses showed the highest indoor radon concentrations among all housing types $(p=0.026$ vs. semi-detached houses $\left[\leq 661.157 \mathrm{~m}^{2}\right]$ ). Residences at ground level showed significantly higher indoor radon concentrations than residences above ground level $(p=0.006)$. Although indoor radon concentrations were relatively lower in residences that used concrete/cement and no gypsum board as building materials, there were no statistical differences therein, compared to homes that did not $(p>0.05$, Table 1$)$. Daily ventilation reduced mean indoor radon concentrations to $39.7 \mathrm{~Bq} / \mathrm{m}^{3}$, remarkably lower than concentrations in homes that were not ventilated once a day $(p<0.001)$. There were no differences in concentrations according to groundwater use $(p>0.05)$. Interestingly, indoor radon concentrations were higher when there was cracks around measuring equipment and

Table 1. Indoor radon concentrations according to residential environment

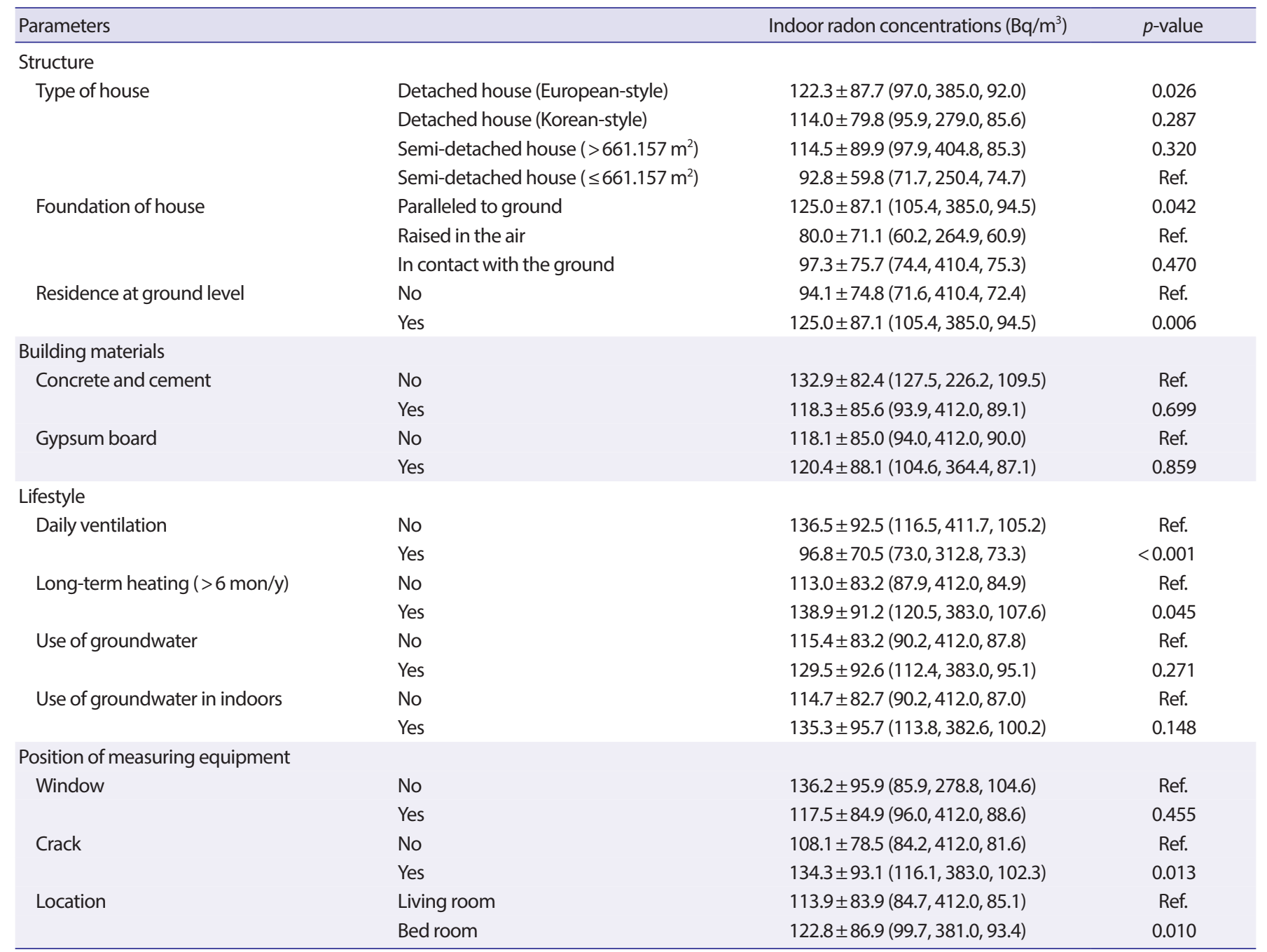

Radon concentrations are presented as mean \pm standard deviation (median, range, geometric mean). Radon concentrations were assessed by a generalized estimating equation with a linear model. Each category compared with reference values.

Ref, reference. 
Table 2. Factors predictive of high radon concentrations

\begin{tabular}{|c|c|c|c|c|c|c|c|}
\hline Parameters & $\begin{array}{c}<74 \\
\mathrm{~Bq} / \mathrm{m}^{3}\end{array}$ & $\begin{array}{l}74-100 \\
\mathrm{~Bq} / \mathrm{m}^{3}\end{array}$ & $\begin{array}{c}100-148 \\
\mathrm{~Bq} / \mathrm{m}^{3}\end{array}$ & $\begin{array}{c}148-200 \\
\mathrm{~Bq} / \mathrm{m}^{3}\end{array}$ & $\begin{array}{c}\geq 200 \\
\mathrm{~Bq} / \mathrm{m}^{3}\end{array}$ & $p$-value & OR $(95 \% \mathrm{Cl})$ \\
\hline \multicolumn{8}{|c|}{$\begin{array}{l}\text { Characteristics around residence from Ministry } \\
\text { of Environment }\end{array}$} \\
\hline Greenery ratio (\%) & $58.9 \pm 16.5$ & $61.3 \pm 18.9$ & $64.4 \pm 19.9$ & $65.2 \pm 20.5$ & $66.2 \pm 21.3$ & 0.017 & $1.009(1.002,1.016)$ \\
\hline Impermeable layer ratio (\%) & $20.3 \pm 18.7$ & $20.5 \pm 20.6$ & $16.0 \pm 19.2$ & $12.9 \pm 18.2$ & $14.6 \pm 19.8$ & 0.043 & $0.992(0.985,1.000)$ \\
\hline Radon levels in groundwater (Bq/L) & $54.2 \pm 16.0$ & $52.5 \pm 16.3$ & $53.4 \pm 17.0$ & $54.6 \pm 18.4$ & $56.1 \pm 17.9$ & 0.604 & $1.002(0.994,1.010)$ \\
\hline \multicolumn{8}{|l|}{ Structure } \\
\hline Residence at ground level & $152(72.4)$ & $46(74.2)$ & $76(81.7)$ & $54(88.5)$ & $82(89.1)$ & 0.003 & $1.607(1.174,2.202)$ \\
\hline \multicolumn{8}{|l|}{ Building materials } \\
\hline Concrete and cement & $207(98.6)$ & $62(100.0)$ & $91(97.8)$ & $60(98.4)$ & $90(97.8)$ & 1.000 & $0.810(0.000,-)$ \\
\hline Gypsum board & $45(21.4)$ & $8(12.9)$ & $20(21.5)$ & $15(24.6)$ & $19(20.7)$ & 0.942 & $1.012(0.735,1.394)$ \\
\hline Use of groundwater indoors & $32(15.2)$ & $13(21.0)$ & $14(15.1)$ & $13(21.3)$ & $25(27.2)$ & 0.097 & $1.322(0.951,1.838)$ \\
\hline \multicolumn{8}{|l|}{ Position of measuring equipment } \\
\hline Window & $198(94.3)$ & $58(93.5)$ & $92(98.9)$ & $60(98.4)$ & $82(89.1)$ & 0.586 & $0.833(0.431,1.610)$ \\
\hline Crack & $69(32.9)$ & $23(37.1)$ & $42(45.2)$ & $27(44.3)$ & $46(50.0)$ & 0.022 & $1.354(1.046,1.753)$ \\
\hline Location (bedroom) & $102(48.6)$ & $34(54.8)$ & $49(52.7)$ & $34(55.7)$ & $51(55.4)$ & 0.013 & $1.131(1.027,1.246)$ \\
\hline
\end{tabular}

Data presented as mean \pm standard deviation and $\mathrm{n}(\%)$.

Characteristics around residence from Ministry of Environment are presented as mean \pm standard deviation (median, range). To obtain association of each parameter according to high radon concentrations group, $p$-value and odds ratio were applied by a generalized estimating equation based on multinomial probability distribution with a cumulative probit link function.

OR, odds ratio; $\mathrm{Cl}$, confidence interval.

when measuring devices were placed in bedrooms $(p=0.013$ and $p=$ 0.010 , respectively).

\section{Factors predictive of high indoor radon concentrations}

Table 2 presents odds ratios for factors likely to affect indoor radon concentrations. Higher greenery ratio and lower impermeable layer ratio were associated with a significantly greater risk of a residence having higher indoor radon concentrations (i.e., $\left.\geq 200 \mathrm{~Bq} / \mathrm{m}^{3}\right)(p=0.017$ and $p=0.043$, respectively). Also, a residence at ground level, ventilation less than once a day, long-term heating over half a year, a crack around measuring equipment, and bedrooms significantly increased the rates of houses likely to show high indoor radon concentrations, from $<74 \mathrm{~Bq} /$ $\mathrm{m}^{3}$ to $\geq 200 \mathrm{~Bq} / \mathrm{m}^{3}$ (72.4\% to $89.1 \%$ [ $\left.p=0.003\right], 43.8 \%$ to $71.7 \%[p<0.001]$, $16.2 \%$ to $31.5 \%$ [ $p=0.031$ ], $32.9 \%$ to $50.0 \%$ [ $p=0.022$ ], and $48.6 \%$ to $55.4 \%$ $[p=0.013]$, respectively), compared to their counterparts. A negative correlation was noted between greenery and impermeable ratio $\left(\mathrm{r}_{\text {spearman }}\right.$ $=-0.872, p<0.001$, data not shown). Meanwhile, greenery and impermeable layer ratios for each residence were positively correlated with indoor radon concentrations $\left(\mathrm{r}_{\text {spearman }}=0.196, p<0.001\right.$ and $\mathrm{r}_{\text {spearman }}=-0.192$, $p<0.001)$. Use of groundwater indoors and radon levels in groundwater exhibited no statistical association with higher indoor radon concentrations group ( $p=0.097$ and $p=0.604$ ). Among residences that use of groundwater indoors, those with high levels of radon in the groundwater tended to show higher indoor radon concentrations, although statistical significance was lacking $(p=0.740)$.

To clarify factors affecting high indoor radon concentrations, decision tree analysis was performed (Figure 1). Therein, daily ventilation and greenery ratio were identified as significant nodes from which to identify residences with higher indoor radon concentrations by exhaustive CHAID ( $p<0.001$ and $p=0.012$, respectively). Daily ventilation increased the probability of radon concentrations in homes being $<74 \mathrm{~Bq} /$ $\mathrm{m}^{3}$ by $15.5 \%$ than ventilation less than once a day. Meanwhile, lack of daily ventilation and having a greenery ratio $(\geq 65 \%)$ increased the chances of homes showing radon concentration over $200 \mathrm{~Bq} / \mathrm{m}^{3}(15.3 \%$ vs. daily ventilation and $8.4 \%$ vs. lack of daily ventilation and having a greenery ratio $[<65 \%]$, Figure 1 ). 


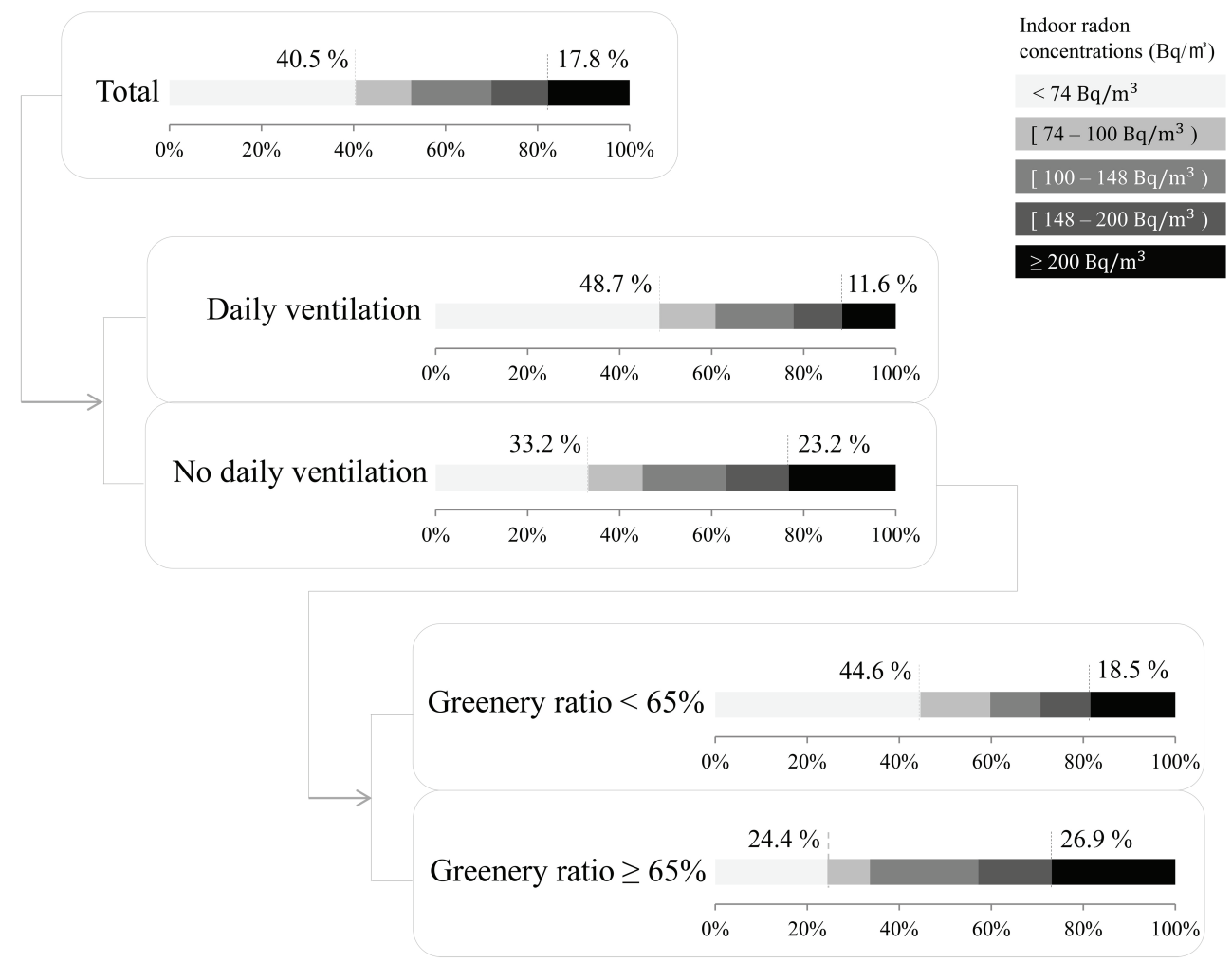

Figure 1. Decision algorithm for predicting higher radon concentrations. Decision tree analysis was conducted to predict higher radon concentrations and validated by a random sampling approach with $20 \%$ testing set. $p$-value obtained from $\chi^{2}$ test to determine the vest next split variable. Daily ventilation $(p<0.001)$ and greenery ratio $(p=0.012)$ were identified as significant nodes. Dashed reference line presents probability of $<74 \mathrm{~Bq} / \mathrm{m}^{3}$ and $\geq 200 \mathrm{~Bq} / \mathrm{m}^{3}$.

\section{Affected model for predicting indoor radon concentrations}

Our final multivariate model was constructed using SEM (Figure 2). To predict indoor radon concentrations, several affected factors were identified from the univariate analysis $(p<0.05)$. In total, seven factors were selected and included in the affected model, including foundation type, a crack around measuring equipment, greenery ratio, radon levels in groundwater, long-term heating, number of ventilations in a week, and measurement in a bedroom. Greenery ratio was selected for inclusion in the affected model, because greenery ratio did not reflect agricultural area. Moreover, we found that impermeable layer ratio, greenery ratio, and indoor radon concentration were highly correlated with each other, which implied that radon amounts in the ground underneath a building could be an important factor affecting indoor radon concentrations. Accordingly, we assumed that radon levels in groundwater would be an indirect predictor of radon amounts in the ground beneath a building.

Figure 2 outlines the constructed model, in which rectangles and circles represent observed variables and error terms (el to e8), respectively. Singleheaded arrows represent the impact of one variable on another, and dou- ble-headed arrows represent covariance between two variables. The final model obtained acceptable fit with $\chi^{2} / d f=1.192$ (GFI $=0.990$ and RM$\mathrm{SEA}=0.019$ ). A crack was positively correlated with residences at ground level and radon levels in groundwater (correlation: $r=0.223$ and $r=0.138$, respectively). A residence at ground level and crack were positively associated with greenery ratio $(p<0.001$ and $p<0.001)$, while radon levels in groundwater were negatively associated with daily ventilation $(p=0.001)$ We noted direct positive relationships for greenery ratio $(p<0.001)$ and inverse relationships for daily ventilation $(p<0.001)$ with indoor radon concentrations. Greenery ratio also showed indirect relationships with long-term heating and ventilation in relation to indoor radon concentrations. Bedrooms held no statistical significance in this model.

\section{DISCUSSION}

To our knowledge, the present study is the first to examine the combined influence of geographical characteristics, groundwater, and lifestyle factors on indoor radon concentrations. The main factors affecting 


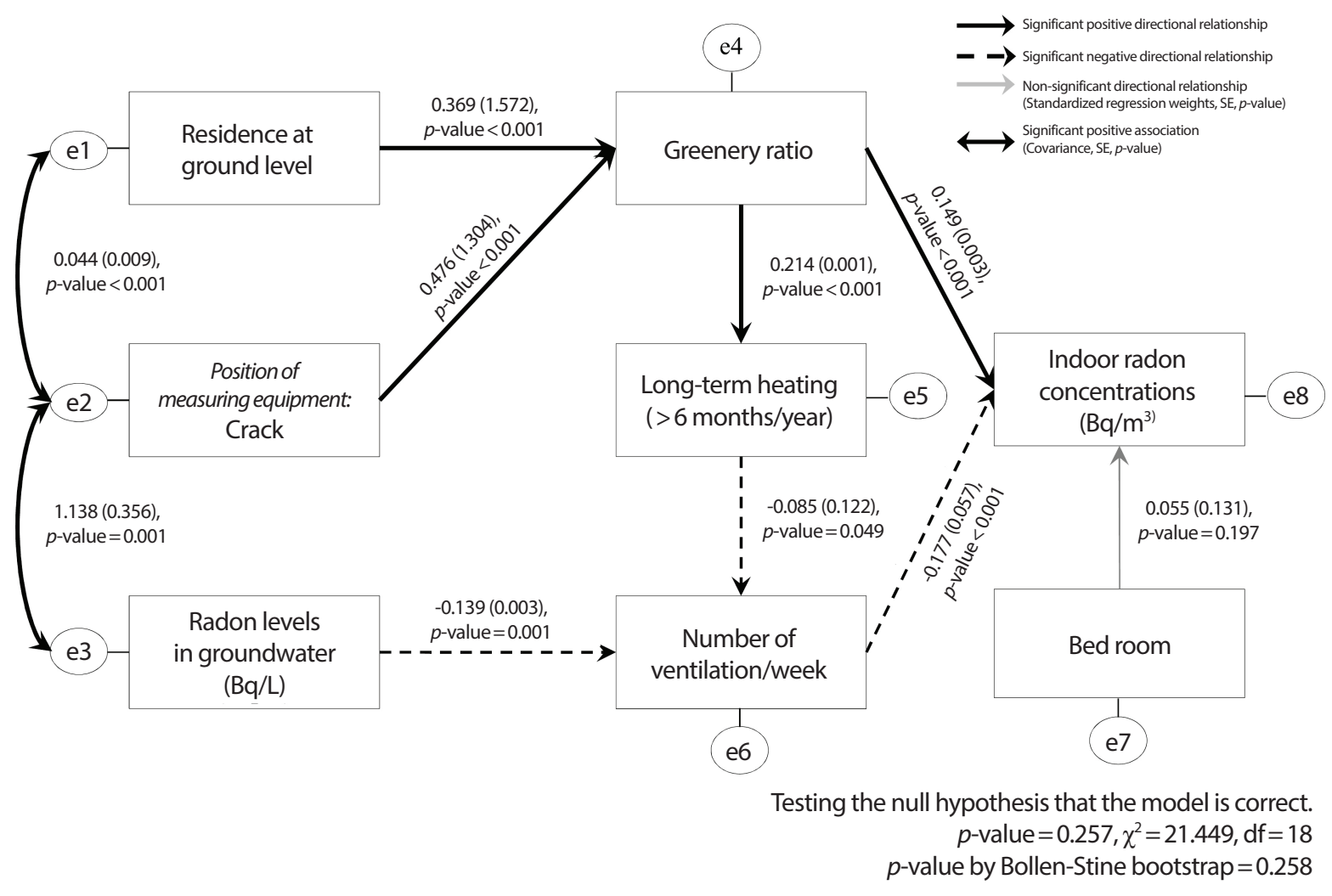

Figure 2. Schematic representation of the affected model of indoor radon concentrations. Coefficients of regression weights indicating relationships between factors are indicated with single-headed arrow. Covariance measuring similar behaviors between error terms is indicated with a double-headed arrow. Rectangles and circles represent observed variables and error terms (e1 to e8), respectively. $p$-values on arrows obtained by maximum likelihood method. This model showed acceptable fit with $\chi^{2} / d f=1.192(\mathrm{GFI}=0.990$ and RMSEA=0.019).

indoor radon concentration were greenery ratio and ventilation rate. A high greenery ratio and low ventilation rate significantly increased indoor radon concentrations. For residences with a greenery ratio $\geq 65 \%$, the rate of homes with indoor radon concentrations $\geq 200 \mathrm{~Bq} / \mathrm{m}^{3}$ was $26.9 \%$ for homes without daily ventilation, compared to $11.6 \%$ for homes that were ventilated daily. In support thereof, a previous study demonstrated that radon exhalation rates from surfaces and ventilation rates are major factors affecting indoor radon concentrations [16]. In our model, we replaced the exhalation rate of radon from surfaces with radon concentrations in groundwater and greenery ratios, which were readily available as national survey data. In addition, building structure, cracks in the building, and long-term heating can indirectly influence indoor radon concentrations via greenery ratio. As part of efforts to reduce indoor radon concentrations, several prediction model using indoor ventilation and outdoor radon concentration were conducted for predicting the indoor radon concentration [17-19]. However, there was no approach to identify the multiplex variables that affect indoor radon concentrations and to identify the relationships between them.

Radon levels are remarkably higher in groundwater than in surface water [1]. When it is boiled indoors and used in showers, groundwater can be a major source of indoor radon levels as radon gas is released [20]. In the present study, among residences that used groundwater indoors, those with high levels of radon in the groundwater tended to show higher indoor radon concentrations; however, we noted no statistical association between use of groundwater indoor and indoor radon concentrations.

Although bedrooms showed no significant associations with indoor radon concentrations in the SEM, indoor radon concentrations were significantly higher in bedrooms than in living rooms by about $8.9 \mathrm{~Bq} / \mathrm{m}^{3}$ $(p=0.010)$. High concentrations of radon in bedrooms stress the need for efforts to reduce radon levels, because one third of the day is spent in the bedroom for sleep. Interestingly, a lack of ventilation and long-term heating over half a year were associated with marked elevations in in- 
door radon concentrations in the present study. These results highlight areas in which strategies to augment lifestyle factors could help reduce indoor radon concentrations.

The present study has a few limitations that warrant consideration. First, we applied SEM to develop a comprehensive model of factors affecting indoor radon concentrations in Korea; however, we could not examine the directionality of noted relationships. Nonetheless, SEM approaches remain useful in understanding relationships among multivariate conditions. Moreover, the directions of factors affecting indoor radon levels presented reasonable fitting score. Also, we used national public data to determine impermeable layer ratio, greenery ratio, and radon levels in groundwater; we did not directly measure these variables around each residence. Additionally, indoor radon concentrations in Korea are measured in the winter season by the government, although, in this study, two residences were measured in October. Nevertheless, there was no statistically significant difference in radon concentrations according measurement start dates.

\section{CONCLUSIONS}

In order to establish indoor radon reduction policies, simply addressing lifestyle factors may not be sufficient. Policymakers should also consider urbanization rates around residential areas and radon distributions in the ground. Finally, appropriate policy proposals based on individual characteristics of a residence, rather than a single comprehensive guideline, may be needed.

This study presents an integrative association among lifestyle, geographical properties, and the structure of homes in relation to indoor radon concentrations. Our results could help with developing comprehensive rules for reducing indoor radon concentrations in Korea.

\section{REFERENCES}

1. Mustafa AZ, Krewski D. Health effects of radon: a review of the literature. Int J Radiat Biol 2009;85(1):57-69.

2. Lubin JH, Boice JD, Edling C, Hornung RW, Howe GR, Kunz E, et al. Lung cancer in radon-exposed miners and estimation of risk from indoor exposure. J Natl Cancer Inst 1995;87(11):817-827.

3. Alderson L. A creeping suspicion about radon. Environ Health Perspect 1994;102(10):826-830.
4. World Health Organization. WHO handbook on indoor radon: a public health perspective. WHO: Geneva; 2009, p. 3-16.

5. Henschel DB, Scott AG. Some results from the demonstration of indoor radon reduction measures in block basement houses. Report for June 1985-February 1987. Environ Int 1989;15(1-6):265-270.

6. Yoon JY, Lee JD, Joo SW, Kang DR. Indoor radon exposure and lung cancer: a review of ecological studies. Ann Occup Environ Med 2016; 28(15):1-9.

7. Iakovleva V, Karataev V. Factors determining the formation of radon levels inside buildings. Radiats Biol Radioecol 2004;45(3):333-337.

8. Akerblom G, Falk R, Lindgren J, Mjönes L, Östergren I, Söderman A, et al. Natural radioactivity in Sweden, exposure to internal radiation. Rättvik, Sweden; 2005, p. 211-214.

9. George A. The history, development and the present status of the radon measurement programme in the United States of America. Radiat Prot Dosimetry 2015;167(1-3):8-14.

10. Shin K, Leem CS. A reference system for internet based inter-enterprise electronic commerce. J Systems Software 2002;60(3):195-209.

11. Choei NY. The viability of the procedural modeling technique in scenario analyses of the residential site plans. Arch Civ Eng 2016:136144.

12. Cho BW, Choo CO, Yun U, Lee BD, Hwang JH, Kim MS. Hydrogeochemical characteristics, occurrence, and distribution of natural radioactive materials (uranium and radon) in groundwater of Gyeongnam and Gyeongbuk provinces. J Eng Geol 2014;24(4):551-574.

13. Jeon JS, Kim DC. Distribution of 222 rn concentration in seoul subway stations. Korean Soc Environ Eng 2006;28(6):588-595 (Korean).

14. Ju BK, Kim MS, Jeong DH, Hong JK, Kim DS, Noh HJ, et al. Environmental characteristics of naturally occurring radioactive materials (238 U, $222 \mathrm{Rn}$ ) concentration in drinking groundwaters of metamorphic rock areas: Korea. J Soil Groundwater Environ 2013;18(3):82-92 (Korean).

15. Schreiber JB, Nora A, Stage FK, Barlow EA, King J. Reporting structural equation modeling and confirmatory factor analysis results: a review. J Educ Res 2006;99(6):323-338.

16. Chauhan N, Chauhan R, Joshi M, Agarwal T, Aggarwal P, Sahoo B. Study of indoor radon distribution using measurements and CFD modeling. J Environ Radioact 2014;136:105-111.

17. Meisenberg O, Tschiersch J. Thoron in indoor air: modeling for a better exposure estimate. Indoor Air 2011;21(3):240-252. 
18. Janssen M. Modeling ventilation and radon in new Dutch dwellings. Indoor Air 2003;13(2):118-127.

19. Blondeau P, Iordache V, Poupard O, Genin D, Allard F. Relationship between outdoor and indoor air quality in eight French schools. In- door Air 2005;15(1):2-12.

20. Becker AP, Lachajczyk TM. Evaluation of waterborne radon impact on indoor air quality and assessment of control options. US Environmental Protection Agency: Washington, D.C.; 1984, p. 1-10.

\section{국문초록}

생활 습관, 주거지 주변 녹지 비율 및 지하수 내 라돈 농도 따른 실내 라돈 농도 영향 모델

라돈 및 그 자손은 폐암을 일으키는 환경적 위험인자로, 일상 활동 및 수면 등으로 많은 시간을 보내는 실내 라돈 농도 관리는 필수적이 다. 이를 위해서는, 주거지를 둘러싼 개인적, 사회적, 환경적 요소에 대한 총체적 접근이 필요하다. 따라서 본 연구는 실내 라돈 농도에 영 향을 미치는 다양한 인자를 찾아내고, 이를 활용한 포괄적 모델을 구축하고자 한다. 건축 자재 및 생활 양식을 포함한 주거 환경에 대한 자료를 얻기 위해 설문을 실시하였고, 의사결정트리 및 구조 방정식 모델링을 활용하였다. 그 결과 주거지 주변 녹지 비율, 불 투과성 층 비율, 주택과 지면의 맞닿은 상태, 매일 환기 습관, 난방 습관, 측정 장치 주위의 균열 및 침실여부는 실내 라돈 농도와 유의한 연관성을 보였다. 매일 환기 습관을 가질 경우 실내 라돈 농도가 $200 \mathrm{~Bq} / \mathrm{m}^{3}$ 이상인 비율이 $11.6 \%$ 로 줄었다. 한편 매일 환기습관이 없는 주거자의 주거지 주변 녹지 비율이 $65 \%$ 이상이면 매일 환기 습관이 있는 주거자와 비교하여 $15.3 \%$ 의 비율이 증가하였다. 구축된 포괄적 모델의 실내 라돈 농도에 직접 영향을 미치는 인자는 주거지 주변 녹지 비율과 환기율이었다. 제시된 모델로 국내 라돈 농도에 대한 개인의 지리 적 특성, 지하수 및 생활 양식 요소의 결합된 영향을 확인할 수 있었다.

주제어: 실내공기, 라돈 조사, 환기, 지리적 특성, 생활습관, 지하수 